\title{
Appropriate Ratio Of Wild Yam (D. praehensilis) Flour To Add To Wheat Flour For Breadmaking Process
}

\author{
Songuimondenin Soro, Jean D. Kouassi-Koffi*, Hubert K. Konan, and Eugène J-P. Kouadio
}

\section{ABSTRACT}

The objective of this work was to find the suitable incorporation ratio of $D$. praehensilis flour into wheat flour in order to obtain appropriate bread. All incorporation reduced bread making potential as wet gluten, dry gluten, gluten index and gluten water binding capacity. These values decrease significantly from $(28.4 \%$ to $21.7 \%),(10.3 \%$ to $7.54 \%),(95$ to $88 \%)$ and $(18.1$ to $14.16 \%)$ respectively for wet gluten, dry gluten, gluten index and gluten water binding capacity. The yam flour incorporation reduced the dough rising potential and the final bread volume. The specific volume decreased from 3.26 to $1.37 \mathrm{~cm}^{3} /$ g. During dough fermentation, highest volume values were ranged from $135.45 \mathrm{~cm}^{3}$ to $100.06 \mathrm{~cm}^{3}$, respectively from control (WF) to WYF-25 flours. Flours damaged starch content increasing from $21.8 \%$ to $28.9 \%$, was responsible of the Hagberg Falling Number reduction related to increase of amylase's activities. The Falling Number of composite flours was ranged from 327s to $357 \mathrm{~s}$, compared to control flour dough (362s). This induced the increasing of dough hydration from $62 \%$ to $82 \%$. Increase in dough Tenacity (from 103 to $222 \mathrm{mmH}_{2} \mathrm{O}$ ) and $P / L$ configuration ratio (from 0.93 to 7.93 ) were noticed. The sensory evaluation showed that below $10 \%$ of yam flour substitution to wheat flour the final bread crumb colour, aroma, taste, and overall are acceptable by consumers.

Keywords: breadmaking, composite flour, Dioscorea praehensilis, gluten, starch.

\section{INTRODUCTION}

Yam is the staple food of many people in Africa [1], and the main food crop, ahead of cassava, plantain and rice [2]. Huge post-harvest losses, up to $20-30 \%$, are reported in yam production $[3,4,5]$. The main world yam producing countries are West African: Nigeria (45 Million Tonnes (MT)), Ghana (7.11 MT), Côte d'Ivoire (5.8 MT) and Benin (3 MT) [2]. However, post-harvest losses are still increasing in these countries [6]. As a result, periods of severe food insecurity prevalence are recurrent and longer from one year to another.

Dioscorea praehensilis cv "Kokoassé" is a wild yam that produces particularly large tubers with very high starch content [7] and is therefore an ideal choice to solve undernourishment prevalence. Today, in many rural areas, this wild yam has naturally emerged during dietary difficulties as a famine food highly prized by local populations. In fact, $D$. praehensilis has numbers of morphologic, physiologic, genetic and especially organoleptic similarities with the highly prized and cultivated varieties of the $D$. cayenensis - D. rotundata complex $[8,9]$. Thus, some forms of $D$. praehensilis are commonly cultivated $[10,11,12,13]$. However, vulgarization of $D$. praehensilis is compromised by the high predisposition of the tuber to tubers.
Published Online: May 5, 2020

ISSN: 2684-5199

DOI :10.24018/ejbio.2020.1.2.20

\section{S. Soro}

Université Nangui Abrogoua (UNA), Abidjan, Côte d'Ivoire

(e-mail: songui2soro@yahoo.fr)

\section{J. D. Kouassi-Koffi *,}

Université Nangui Abrogoua (UNA), Abidjan, Côte d'Ivoire

(e-mail: k_kjd@yahoo.fr)

\section{K. H. Konan}

Université Nangui Abrogoua (UNA), Abidjan, Côte d'Ivoire

(e-mail:konankouassihubert@yahoo.fr)

\section{E.J-P. Kouadio}

Université Nangui Abrogoua (UNA), Abidjan, Côte d'Ivoire

(e-mail: nkouadiop@yahoo.fr)

*Corresponding Author

degradation. These tubers are highly perishable, as organoleptic quality depreciation and physical deterioration start immediately the day after harvest, if not consumed. This extreme perishability of $D$. praehensilis tubers limits postharvest storage time and any marketing opportunities of fresh tubers. Generally, harvested tubers are immediately auto consumed under different consumption forms as inventoried by Amani et al. [14]. But there are no extension possibilities of such processes on industrial scale for fresh $D$. praehensilis

In these conditions, $D$. praehensilis does not fully ensure its function of famine food. The transformation of yam tubers into flour is a technology that can extend the post-harvest storage time and open new possibilities and multiple applications. Food flours always offer more opportunities for applications in food technology than the raw materials from which they are extracted. In some West African countries such as Benin, Nigeria, Togo, yams are used de make chips and then flour [15], [16]. The flour obtained is used in numbers of traditional preparations such as "amala", "telibo", "wassa-wassa" or "tubaani", well known throughout West African region ([16], [17] [15]. The making of yam flour desserts "halaya" has been also reported by Rosario and Malit [18] in the Philippines. Yam flour is also used to make child's 
foods [19]. However, there are no similar activities in the use of $D$. praehensilis, especially in Côte d'Ivoire.

Thus, the possibility of incorporating this yam flour into wheat flour in bread making processes would be in adequacy with the FAO program of composite flours aims [20]. The objective of this strategy was to encourage inexpensive local flours use in bakery, in order to reduce wheat imports of some countries' government. Some sub-Saharan African countries like Côte d'Ivoire spend about 100 Billion per year in wheat imports since 2011 [21].

The main problem in wheat flour substitution by local flours is the absence of gluten (essential protein in bread making) in these local products. Due to this lack of gluten, yam flour is not a bread making one and should be combined with wheat flour for bread making. The purpose of these research activities is to determine the optimal substitution proportion of wheat flour and to establish conditions to improve it., Cassava flour is widely incorporated into wheat flour for bread made in some West African countries such as Nigeria. This country recommended to its millers through a cassava bread initiative, the partial substitution of $10 \%$ of wheat flour by cassava one [22]. In Côte d'Ivoire, acceptable breads made of $15 \%$ of local flour (maize or cassava) has been proven, testified and spread by the West Africa Agricultural Productivity Program (WAAPP/WAAPP) [23]. Similar works led to acceptable quality of breads with $15 \%$ of sweet potato flour $[24,25]$. It has been also reported that $25 \%$ of wheat substitution ratio can be achieved with the yams Dioscorea rotundata, Dioscorea alata and Dioscorea bulbifera [26]. Coursey and Ferber [15] stated that the partial substitution of wheat flours up to $20 \%$ by yam flour could produce good quality of breads. Overall, it appears from numbers of previous works, that beyond $20 \%$ incorporation of local flours, it becomes difficult to have good breads. But acceptable special breads, cookies and pastries such as cakes, have been reported with higher substitution rates (50 to $100 \%)[15,26,27]$. Partial substitutions of wheat flours by gluten-free $D$. praehensilis flours may inevitably lead to a depreciation of the technological potential. Baking quality of the composite flours as the deficit of gluten in local flour seems difficult to manage in bakery.

Transformation of $D$. praehensilis tubers into flour would definitively solve conservation problems and open new economic ways of different countries. In the other hand, incorporate $D$. praehensilis flour into wheat flour to make bakery products would open new employment opportunities in the bakery industry, encourage peasants in producing more D. praehensilis tubers and reduce some countries wheat import expenditures.

The aim of the present work is to ensure the valorization of the wild yam $D$. praehensilis and to contribute in a relevant way to the improvement of food security. The substitution of wheat flour by flour of this yam in breadmaking processes would be one of the ways of its valorization. Thus, in order to evaluate the influence of the partial substitution of wheat flour by the wild $D$. praehensilis yam flour in breads production, the evolution of some functional, bakery and rheological characteristics in flours, dough and loaves will be investigated versus the substitution degree.

\section{MATERIALS AND METHODS}

\section{A. Ingredients for composite Bread Dough}

The bread samples were prepared by mixing ingredients such as flour, water, yeast, sugar, fat and salt. Fresh tubers of wild yam $D$. praehensilis with variables lengths $(20-63 \pm$ $4.46 \mathrm{~cm})$ and variable weights $(0.5-5 \mathrm{~kg})$ was used without any chemical or protein supplementation. They were harvested at physiological maturity (August to November) in six villages (Hallikro, Ketasso, N'Drikro, Kouassikro, AvocaKoffikro and Diabykro) of Divo ( $\left.5^{\circ} 50^{\prime} \mathrm{N} ; 5^{\circ} 22^{\prime} \mathrm{W}\right)$, Côte d'Ivoire. Harvested tubers collected were transported the same day to Abidjan in jute bags for laboratory tests. Wheat flour type 55 produced from variety "Malika" and obtained from 100\% soft wheat (Côte d'Ivoire) was used without any chemical or protein supplementation.

\section{B. Preparation of yam flour samples}

D. praehensilis Yam tubers were peeled, thinly sliced, washed and blanched in boiling water for $5 \mathrm{~min}$. Pieces of precooked yams were left cooling for 25 minutes and cut into chips. Then these chips were dried at $45^{\circ} \mathrm{C}$ for 48 hours using a dryer made of I2T (Société Ivoirienne de Technologie Tropicale). The dried chips were then milled. They automatically passed through a $90 \mu \mathrm{m}$ of mesh size sieve to obtain a final flour [28]. The flour was stored in plastic bags to prevent moisture re-absorption.

\section{Determination of bakery properties of flours}

Damaged starch content was evaluated using the SDmatic (Chopin) at different flour fractions.

Gluten content was tested by standard method for wet gluten (NA.735.1991, ISO 55 31) and for dry gluten (NA, 736.1991, ISO 6646). Gluten index was then calculated. Zeleny's sedimentation index test was determined as described by standard method (NA.1184.1994 E, ISO 5529) using Infrared (INFRANEO, Chopin).

$\alpha$-amylasis activity of the flours was estimated using the Hagberg falling number (Pertens model No. 1500, USA) according to the standard method [29].

\section{Measurement of rheological parameters}

Alveograph Chopin was used to evaluate the final dough rheological characteristics such as dough tenacity $\mathrm{P}$, dough extensibility L, elasticity index I.e and dough baking strength W. The parameters were thus obtained according to the NI.03.07.010 method. It used $250 \mathrm{~g}$ of each dough sample to perform four (4) main steps such as Mixing flour and salty water, molding of five (5) calibrated pieces of dough, Fermentation and automatic inflation of each piece of dough until the burst of bubble.

\section{E. Measurement of the dough swelling speed}

Dough's rising speed during its fermentation was done. 30 $\mathrm{g}$ of dough was placed in cylindrical cell and the surface was leveled to obtain initial volume $\mathrm{V}_{0}$. The cell was then placed into the fermentation chamber at $32{ }^{\circ} \mathrm{C}$ for 3 hours to follow the rise of flour dough. The volume of the dough was measured every $30 \mathrm{~min}$ during the test. The different values are then used to calculate the dough swelling speed.

\section{F. Bread making process and hydration estimation}

Bread samples were done using 100\% wheat flour, 5\%, 
TABLE 1: FORMULATION OF FLOUR DOUGH SUBSTITUTED

\begin{tabular}{|c|c|c|c|c|c|c|}
\hline \multicolumn{7}{|c|}{ FORMULATION } \\
\hline Samples & WF & WYF-5 & WYF-10 & WYF-15 & WYF-20 & WYF-25 \\
\hline Flour (kg) & 2 & 2 & 2 & 2 & 2 & 2 \\
\hline (Malika) (g) & 2000 & 1900 & 1800 & 1700 & 1600 & 1500 \\
\hline (Yam) (g) & 0 & 100 & 200 & 300 & 400 & 500 \\
\hline Water (ice) (g) & 420 & 420 & 420 & 420 & 420 & 420 \\
\hline Water (liquid) (ml) & 820 & 860 & 900 & 1020 & 1100 & 1220 \\
\hline Salt 1.6\% (g) & 32 & 32 & 32 & 32 & 32 & 32 \\
\hline Dry yeast $1 \%(\mathrm{~g})$ & 20 & 20 & 20 & 20 & 20 & 20 \\
\hline (Ascorbic Acid) (g) & 10 & 10 & 10 & 10 & 10 & 10 \\
\hline
\end{tabular}

$10 \%, 15 \%, 20 \%$ and $25 \%$ of yam flour incorporation to wheat flour. We obtained respectively: WF, WYF-5, WYF10, WYF-15, WYF-20 and WYF-25 (Table 1).

Breads are produced according to standard BIPEA protocol (Standard AFNOR NF V03-716). Mixing of ingredients flour, yeast, improver, and water, kneading, fermentation and baking. Two (2) $\mathrm{kg}$ of flour was weighed (technical KERN, EMB (precision $\pm 1 \mathrm{~g}$ ) scale) and placed in DANZI Forni spiral mixer of $3 \mathrm{~kg}$. Water (liquid and ice), yeast and ascorbic acid are then added to the mixture. Ingredients are homogenized for $4 \mathrm{~min}$ with a first slow speed $(\mathrm{V} 1=80 \mathrm{rpm})$. Dough was then rest $5 \mathrm{~min}$ for relaxation and started a second speed $(\mathrm{V} 2=160 \mathrm{rpm})$ for $6 \mathrm{~min}$. Salt is then done 5 minutes before the end of mixing. The required water (liquid and ice) used to obtain the desired dough texture is used to calculate the hydration rate. The dough was rest again during $15 \mathrm{~min}$ before the beginning of the fermentation (1st fermentation or bulk fermentation). Bread dough are divided into different pieces (270 g pieces which undergone another rest period (relaxation) of $45 \mathrm{~min}$ ). Dough samples were shaped manually to obtain desired forms. Each sample was passed to a BONGARD moulder calibrated to obtain standard form of bread (Standard NF, V. 03-716). After shaping, doughs were then placed into the fermentation chamber at $32^{\circ} \mathrm{C}$ for $\mathrm{t} 3$ hours. At the end of the fermentation, doughs were cut with specific knife and put into a DANZI FORNI oven at $260^{\circ} \mathrm{C}$ during 25 min for baking (Standard NF, V. 03-716). Final breads were finally removed from the oven and rest at $25^{\circ} \mathrm{C}$ during $120 \mathrm{~min}$ for relaxation.

\section{G. Physical properties of samples bread}

Physical characteristics of bread samples such as loaf weight, loaf volume, specific loaf volume, density, Crack and color were evaluated.

Loafs weight, loaf volume and specific loaf volume were determined using the rapeseed and sorghum grains displacement method. Specific loaf volume (SLV) was calculated as the ratio of loaf volume and the weight while loaf. The bread density was calculated as the ratio of loaf weight and the volume. Crack formation was evaluated visually.

\section{H. Sensory evaluation of samples bread}

Breads samples were evaluated using sensory parameters such as color, aroma, texture (crunchiness), taste (flavor) and overall acceptability. Breads samples were judged by a tasting panel of 15 panelists from the staff of the MMCI and students of University Nangui Abrogoua (UNA). Ratings were made on a hedonic scale of 9 points: 9 (I loved it a lot) to 1 (I hated it) as described by Koko et al. [30].

\section{Statistical Analysis}

Apart from hydration data carried from Bread making process, all analyses were carried out in triplicates. Results were expressed by means of $\pm \mathrm{SD}$.

Statistical significance was established using one-way analysis of Variance (ANOVA) models to estimate the effect of boiling times on functional properties of flour from the wild yam $D$. praehensilis at $5 \%$ level. Means were separated according to Duncan's multiple range analysis $(\mathrm{P}<0.05)$, using STATISTICA 7 (Statsoft Inc, Tulsa USA Headquarters) and XLSTAT-Pro 7.5.2 (Addinsoft Sarl, ParisFrance).

\section{RESULTS AND DISCUSSION}

\section{A. Flours properties}

Flours granularity, damaged starch, Gluten content, Zeleny and Hagberg falling number were presented in Table 2.

Gluten parameters are wet and dry gluten as well as gluten index and gluten water binding capacity. Results showed no significant difference in dry gluten content and gluten index from the wheat flour (WF) to the WYF5 flour (incorporating $5 \%$ of yam flour). For both these characteristics, significant differences appeared from $10 \%$ of yam flour incorporation. However, there were significant decrease in all gluten parameters $(p \leq 0.05)$ as the substitution ratio increased significantly (high substituted flours). Thus, gluten values are ranged $(28.4 \%$ to $21.7 \%),(10.3 \%$ to $7.54 \%),(95$ to $88 \%)$ and (18.1 to $14.16 \%)$ respectively for wet gluten, dry gluten, gluten index and gluten water binding capacity. The decrease in gluten (wet and dry) may be related to the low gluten content of the gluten free yam flour compared to wheat flour. Wet and dry gluten are quantitative estimation of the gluten while the gluten index is an evaluation of the gluten's quality relatively to its strength and gas retention capacity. Gluten index (GI) is a criterion showing whether. It is qualitatively weak $(\mathrm{GI}<30 \%)$, normal $(\mathrm{GI}=30-80 \%)$, or strong (GI > $80 \%$ ) [31].

Wet gluten values were globally lower than those obtained by Kulkarni et al. [32] in fifty hard wheat flours Values are ranged from 33.5 to $48.7 \%$. Higher values of wet gluten had also been obtained in various wheat flours by many authors $[33,34]$. The wet gluten values in this study were similar with those reported by Tawakalit [35] for wheat and D. dumetorum yams composite flours. Dry gluten content decreased again 
in composite flours. Dry gluten content values were nearby of (14.62\% to $7.90 \%)$ reported by Abang Zaidel et al. [33] in different wheat flours. Similar values of gluten content were reported by Bakare et al. [36] in composite flour of wheat and breadfruit Artocarpus communis Forst flour. These authors reported that dry gluten content values decreased from 12.8 to $9.8 \%$ for wheat and breadfruit composite flours in ratio of $20 \%$. With a ratio of $60 \%$ of wheat flour, these authors testified $5.8 \%$ of dry gluten content. It has been reported that gluten is not exclusively proteins component. Thus, the socalled gluten is constituted by real gluten ( 75 to $80 \%$ ), lipids ( 5 to $10 \%$ ), residual starch ( 8 to $10 \%$ ), reducing sugars ( 1 to $2 \%$ ), cellulose (2\%) and $1 \%$ of mineral [37].

The gluten index decreased in composite flours, from $95 \%$ (FBI0) to $88 \%$ (FBI25). A similar decrease in gluten index was reported by Tawakalit [35] from the composite of wheat and D. dumetorum flours. This author reported that GI values decreased from 91 to $87 \%$. However, this author found that fermentation of the same yam flour led to an unexpected increasing effect in GI with wheat flour substitution ratio increasing. As xanthan gum, gluten acts were as a waterfixing agent [38]. Consequently, in current study, the waterbinding capacity decreased when the wheat flour substitution ratio increased that reduced the gluten content. Many authors specified strong and positive correlation between gluten parameters, the quality of the bread making processes (kneading and fermentation) and the bread volume [32, 33, 39]. Indeed, gluten is made of wheat proteins. These proteins are responsible of the elasticity and extensibility properties of the bread dough. They were essential to produce good bread $[40,41]$. Some authors had observed increase effects of bread volume with the incorporation of some flours such as vegetables in wheat flour [42]. But it is still difficult to produce good bread with theses substitutions [43, 44]. The bread quality depreciates with the increase of wheat flour substitution by Roots, tubers and gluten-free cereals flours. This has been reported by previous works in that the authors $[27,45]$ incorporated cassava, rice, sweet potato, maize or sorghum flours in wheat flour.

The Zeleny index not varied enough with $10 \%$ of yam flourion substitution. Below, this value, the Zeleny index value was approximately $50 \mathrm{ml}$ and there was no important difference between wheat flour and composite flours. This is consistent with previous results showing that below $10 \%$ of yam flour incorporation, the substitution did not present significant affect in the dry gluten and its quality. Below this ratio, the baking quality of gluten is not affected. Previous studies of Buche [46] showed that the Zeleny index gave indication on the gluten water absorption capacity and its swelling ability. Therefore, Zeleny is in relation with the flour proteins quality, especially, the gluten. The Zeleny index provides information on the ability of proteins to form aggregate in acidic mixtures thanks to glutenin content. Beyond $15 \%$ of yam flour incorporation, an important decrease had been observed in the Zeleny index of composite flours. The decrease in this parameter showed a loss of ability of composite flours [47] of D. praehensilis flour is a glutenfree one in baking. In these conditions, any incorporation of flour into wheat flour would lead to a decreasing effect in Zeleny $[48,49]$. However, values of wheat/D. praehensilis yam composite flours remain higher than the standard minimum set at $15 \mathrm{ml}$ by the ISO 5529, [50]. In facts, the bread making ability increases with the Zeleny index increasing. This ability is supposed to be insufficient (Zeleny value less below $16 \mathrm{ml}$ ), medium (Zeleny between $16-25 \mathrm{ml}$ ), good $(25-38 \mathrm{ml})$ and high (Zeleny $>38 \mathrm{ml})$ [51]. According to this author, Zelenys indexes beyond $38 \mathrm{ml}$ may be from hard wheat flour.

Damaged starch content showed important increasing effects as the wheat flour was gradually substituted with the yam flour, values ranged from 21.8 to $28.9 \%$. These values were all higher than those reported by Barak et al. [52]. This author reported damaged starch content values ranged from $5.14 \%$ to $14.79 \%$ in flours for two wheat varieties. The increase in damaged starch content of current study could be related to the milling process of the two flours blended. The milling process had been reported to be a key parameter influencing the starch damage. The milling quality is particularly related to the origin of the starch, the type of action, and the force used $[53,54]$ as well as the content of amylose and lipids. Wheat harshness was also important for milling quality [55]. Some authors suggested that milling is the main factor responsible of starch damage [56]. Millings that give fine flours are associated with high level of damaged starch and high hydration capacity of flours [57]. Mechanical operations are reported to modify physical and chemical characteristics of starch granules, its configuration and digestibility [53, 54, 58]. The increase of starch damages from composite wheat/yam flours was higher damaged starch fraction in yam flour than wheat flour. Finally, the high content of damaged starch of composite flours of this study is due to the fine milling ability of yam flours chips to obtain yam tubers. The wheat flour damaged starch content should be related to the milling process. It is also to the germination of the grains before the milling and even before harvest [59, $60]$.

Damaged starch is a key bakery parameter that would influence several key parameters of bread-making process such as hydration and water absorption [61, 62, 63]. The amylase activity, the stickiness of the dough as well as the loaves crust's color are likely to be influenced by damaged starch too. Increase of damaged starch content can be critical for flour quality, as it would give a sticky texture to the dough [57]. In addition, the use of high damaged starch content flour in bakery would lead to bulky dough, because of high water absorption capacity of the flour. High WAC was associated to excessive bread crust colour. Thus, previous works $[56,64$, 65 ] stated that pale breads are due to low simple sugar content and diastase flours, which are associated to a low extraction ratio. In opposition, "red" loaves are due to the excess content of simple sugars associated, excessive damaged starch and high amylase activity for higher extraction ratio. Thus, the increase of damaged starch content of wheat and $D$. praehensilis yam composite flours leaded to increase amylase activity. Indeed, the damaged starch constitutes a starting substrate for amylases naturally present in wheat flour [64, 66]. These amylases will transform starch into fermentable sugars that can be used by yeast $[64,66]$.

In bakery, the amylases activity is estimated by the Hagberg Falling number. Roussel [67] stated that normal falling number should range from 250 to $300 \mathrm{~s}$. Beyond 300 $\mathrm{s}$ (hypodiastatic flour), the amylase activity is low, whereas 
TABLE 2: EFFECT OF YAM FLOUR INCORPORATION PERCENTAGE ON THE COMPOSITE FLOURS BAKING CHARACTERISTICS

\begin{tabular}{|c|c|c|c|c|c|c|c|}
\hline \multirow{2}{*}{\multicolumn{2}{|c|}{ Bakery characteristics }} & \multicolumn{6}{|c|}{ D. praehensilis yam flour incorporation rate } \\
\hline & & \multirow{2}{*}{$\begin{array}{l}\text { WF } \\
\mathbf{0 \%} \\
28.4 \pm 0.98^{\mathrm{a}}\end{array}$} & \multirow{2}{*}{$\begin{array}{l}\text { WYF-5 } \\
\mathbf{5 \%} \\
26.7 \pm 0.00^{\mathrm{b}}\end{array}$} & \multirow{2}{*}{$\begin{array}{l}\text { WYF-10 } \\
\mathbf{1 0 \%} \\
25.3 \pm 0.31^{\text {bc }}\end{array}$} & \multirow{2}{*}{$\begin{array}{l}\text { WYF-15 } \\
\begin{array}{l}15 \% \\
24.3 \pm 0.00^{\mathrm{c}}\end{array}\end{array}$} & \multirow{2}{*}{$\begin{array}{l}\text { WYF-20 } \\
\text { 20\% } \\
22.51 \pm 0.49^{\mathrm{d}}\end{array}$} & \multirow{2}{*}{$\begin{array}{l}\text { WY-F25 } \\
\text { 25\% } \\
21.7 \pm 1.01^{\mathrm{d}}\end{array}$} \\
\hline \multirow{4}{*}{ Gluten } & & & & & & & \\
\hline & Dry (\%) & $10.3 \pm 0.06^{\mathrm{a}}$ & $9.80 \pm 0.11^{\mathrm{a}}$ & $9.31 \pm 0.05^{\mathrm{b}}$ & $8.67 \pm 0.20^{c}$ & $8.22 \pm 0.08^{c}$ & $7.54 \pm 0.32^{\mathrm{d}}$ \\
\hline & Index GI (\%) & $95 \pm 0.08^{\mathrm{a}}$ & $94 \pm 0.17^{\mathrm{a}}$ & $92 \pm 0.30^{\mathrm{b}}$ & $91 \pm 0.45^{\mathrm{bc}}$ & $89 \pm 0.15^{\mathrm{c}}$ & $88 \pm 0.66^{\mathrm{c}}$ \\
\hline & WBC (\%) & $18.1 \pm 0.18^{\mathrm{a}}$ & $16.9 \pm 0.8^{\mathrm{b}}$ & $15.99 \pm 0.00^{\mathrm{c}}$ & $15.63 \pm 0.80^{\mathrm{c}}$ & $14.29 \pm 0.06^{\mathrm{d}}$ & $14.16 \pm 0.57^{\mathrm{d}}$ \\
\hline \multicolumn{2}{|c|}{ Damaged starch (\%) } & $21.8 \pm 0.22^{\mathrm{a}}$ & $24 \pm 0.15^{\mathrm{b}}$ & $25.2 \pm 0.33^{\mathrm{b}}$ & $27 \pm 0.00^{\mathrm{c}}$ & $28 \pm 0.09^{\mathrm{d}}$ & $28.9 \pm 0.12^{\mathrm{e}}$ \\
\hline \multicolumn{2}{|c|}{ Zeleny index (ml) } & $50 \pm 0.33^{\mathrm{a}}$ & $50 \pm 0.11^{\mathrm{a}}$ & $49 \pm 0.40^{\mathrm{a}}$ & $44 \pm 0.70^{\mathrm{b}}$ & $45 \pm 0.50^{\mathrm{b}}$ & $42 \pm 0.10^{c}$ \\
\hline \multicolumn{2}{|c|}{ Hagberg Falling Number (s) } & $362 \pm 5^{\mathrm{a}}$ & $327 \pm 11^{\mathrm{c}}$ & $346 \pm 2^{b}$ & $352 \pm 1^{\mathrm{ab}}$ & $357 \pm 2^{\mathrm{a}}$ & $348 \pm 1^{\mathrm{b}}$ \\
\hline
\end{tabular}

below $250 \mathrm{~s}$ it is too strong (hyperdiastasic flour).

Even if falling numbers of the current study, ranged from 327 to 362 , suggesting low amylase activities. It appeared that the incorporation of yam flour leads to a slight increase effects in the amylase activity in all composite flours, compared to wheat flour. Low enzymatic activity (high falling number) would be associated to healthy wheat quality [51]. Hsigh enzymatic activity levels of (low fall times) will induces high levels of damaged starch grains. It is essential to have appropriate $\alpha$-amylase activity in order to ensure the hydrolysis of the damaged starch into fermentable sugars as suggested by Tipples [68]. The author suggested that the extent of amylase activity must be limited in order to prevent excessive dextrinization of the starch during the baking process. This would give a sticky dough and an excessive coloration of the final crust. Considerations all these constraints, it appears that the wheat flour used in this study has a low enzymatic activity and a very good quality. It also seems that partial substitution of yam flour induced increasing activities of the enzyme. This means that the incorporation of yam flour brought high damaged starch content. Similar results were reportedd in previous works [56, 65]. Thus, the increase of enzymatic activity in composite flours may be related to the availability of amylose and amylopectin content. These molecules accessibilities are due to the iincrease of damaged starch fraction. Amyloses and amylopectins are that starchy molecules accessible by wheat flour amylases.

\section{B. Dough hydration}

Fig. 1 shows the evolution of the percentage of flours hydration at the end of the kneading process versus the yam flour incorporation level.

The hydration ratio of the dough samples is the quantity of water required to obtain dough with suitable textural characteristics at the end of the kneading process. This final dough may be soft and remains easy de shape manually. The hydration of the control flour was obtained at $62 \%$. This parameter increased with the increase of yam flour proportion to reach $64 \%, 66 \%, 72 \%, 76 \%$ and $82 \%$ respectively for the dough obtained with flours WYF5, WYF10, WYF15 and WYF20 and WYF25. This analysis has therefore shown the need to increase dough hydration when the yam flour incorporation proportion increase. This significant increasing effect of hydration with the increasing proportion of the substitution is leaded to increase damaged starch content and therefore fermentable sugars. High damaged starch and fermentescible sugars quantity are favourable conditions for an increase in the water absorption capacity (CAE) reported by Barrera et al. [69]. Balla et al. [70] also found that the hydration ratio increased with the increase of wheat flour substitution proportion by sorghum flour (SEP 82). These authors stated that suitable kneading of composite flours with appropriate hydration should be perform separately, starting by kneading yam flour before adding wheat flour at last.

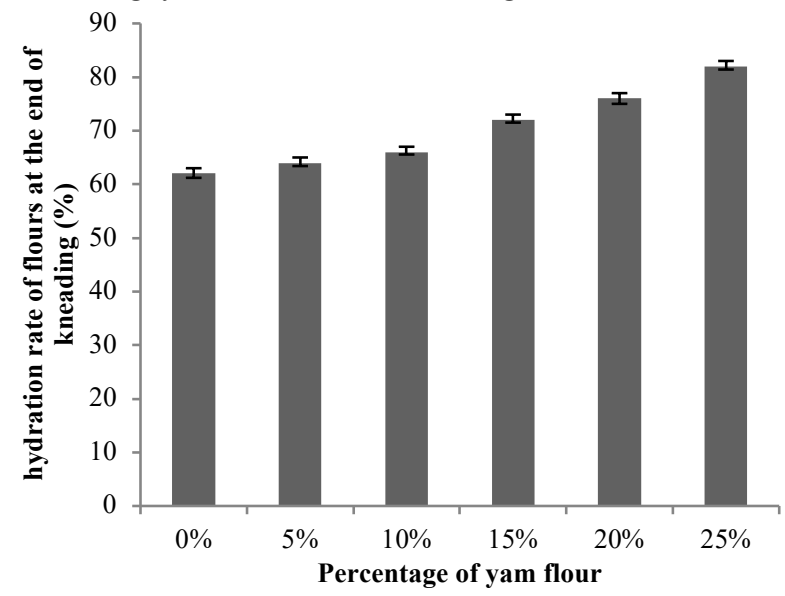

Fig. 1. Evolution of the percentage of flours hydration at the end of the kneading process versus the yam flour incorporation percentage.

\section{Few rheological parameters}

Alveographic data such as Tenacity (P), Extensibility (L), Swelling (G), Configuration Ratio ( $\mathrm{P} / \mathrm{L}$ ) and Baking Strength (W) depreciated rapidly when wheat flour was gradually substituted by $D$. praehensilis yam flour (Table 3 ). Thus, Tenacity (P) of the dough increased from $103 \mathrm{mmH}_{2} \mathrm{O}$ (control) to $222 \mathrm{mmH}_{2} \mathrm{O}$ (at $20 \%$ of yam flour incorporation). This evolution is similar with the results reported by Bakare et al. [36], incorporating breadfruit Artocarpus communis Forst flour into wheat flour. In a study conducted by Balla et al. [70] incorporating sorghum flour into wheat flour, results established that when the substitution ratio increases, the dough tenacity would increase too. High tenacity of bread dough is not desired in breadmaking (current breads) if it could be suitable for the making of some products such as hamburgers [71]. 
TABLE 3: FEW RHEOLOGICAL CHARACTERISTICS OF WHEAT AND COMPOSITE WHEAT/YAM FLOURS

\begin{tabular}{|c|c|c|c|c|c|c|}
\hline \multirow{3}{*}{ Rheological characteristics } & \multicolumn{6}{|c|}{ yam flours Incorporation rate } \\
\hline & WF & WYF5 & WYF10 & WYF15 & WYF20 & WYF25 \\
\hline & $0 \%$ & $5 \%$ & $10 \%$ & $15 \%$ & $20 \%$ & $25 \%$ \\
\hline $\mathrm{P}:$ Tenacity $\left(\mathrm{mmH}_{2} \mathrm{O}\right)$ & $103 \pm 4^{\mathrm{a}}$ & $145 \pm 5^{\mathrm{ab}}$ & $179 \pm 7^{\mathrm{b}}$ & $203 \pm 6^{\text {bc }}$ & $222 \pm 4^{\mathrm{c}}$ & $N D$ \\
\hline $\mathrm{L}:$ Extensibility $(\mathrm{mm})$ & $111 \pm 3^{\mathrm{a}}$ & $67 \pm 1^{\mathrm{ab}}$ & $44 \pm 2^{\mathrm{b}}$ & $32 \pm 1^{\mathrm{b}}$ & $28 \pm 1^{\mathrm{b}}$ & $N D$ \\
\hline $\mathrm{G}:$ Swelling $\left(\mathrm{cm}^{3}\right)$ & $23.5 \pm 1^{\mathrm{a}}$ & $18.2 \pm 0.5^{\mathrm{a}}$ & $14.8 \pm 0.3^{\mathrm{a}}$ & $12.6 \pm 0.3^{b}$ & $11.8 \pm 0.2^{\mathrm{b}}$ & $N D$ \\
\hline $\mathrm{P} / \mathrm{L}$ : configuration ratio & $0.93 \pm 0.02^{\mathrm{a}}$ & $2.16 \pm 0.07^{\mathrm{b}}$ & $4.07 \pm 0.05^{\mathrm{c}}$ & $6.34 \pm 0.11^{\mathrm{d}}$ & $7.93 \pm 0.15^{\mathrm{d}}$ & $N D$ \\
\hline I.e. : elasticity index (\%) & $58.2 \pm 2.3^{\mathrm{a}}$ & $53.9 \pm 1.8^{\mathrm{a}}$ & $49.3 \pm 2.01^{\mathrm{a}}$ & ND & ND & $N D$ \\
\hline W: Bakery strench $\left(\times 10^{-4} \mathrm{~J}\right)$ & $370 \pm 7.50^{\mathrm{a}}$ & $350 \pm 5.66^{\mathrm{b}}$ & $316 \pm 8.45^{\mathrm{c}}$ & $276 \pm 4.50^{\mathrm{d}}$ & $288 \pm 6.67^{\mathrm{d}}$ & $N D$ \\
\hline
\end{tabular}

Compared to results reported by Balla et al. [70], tenacity value reported with wheat flour is similar to that reported in current study. However, the incorporation of $D$. praehensilis yam flour gave higher tenacities values in the composite dough where tenacity value was only $135 \mathrm{~mm} \mathrm{H}_{2} \mathrm{O}$ at $20 \%$ and $160 \mathrm{mmH} 2 \mathrm{O}$ at $40 \%$ for sorghum flour incorporation.

Tenacity is the dough resistance to extensibility. According to Laabidi [72], high tenacity of the dough is associated to its high content of covalent disulfide (S-S) bonds. Branlard [73] stated that a high tenacity (as reported in the current study), may be correlated to predominance of glutenin form. This author specified that high values of tenacity and Gluten Index are likely to affect negatively bread dough extensibility (L) and swelling (G). This may be the reason that these characteristics shown significant decreasing effects in the current study for composite flours. In bakery, the dough extensibility is conferred by gliadins, which are globular proteins of the wheat gluten. This ability of bread dough to extension ensures viscous flow behaviour of the dough [51], whereas glutenins ensures the elasticity $[74,75]$. The swelling index $(\mathrm{G})$ reported for wheat flour FBI0 was 23.5 $\mathrm{cm}^{3}$. This value is in the range of French bread making standard $\left(20\right.$ to $24 \mathrm{~cm}^{3}$ ) [71]. All values obtained for composite flours decrease with the increase of the substitution ratio from 18.2 to $11.8 \mathrm{~cm}^{3}$ [71]. These values were therefore below of the minimum desired value $\left(20 \mathrm{~cm}^{3}\right)$ set by French bread making standards. The swelling index (G) gives information on the extensibility of the dough and makes it possible to make estimations about the dough ability to retain carbon dioxide $\left(\mathrm{CO}_{2}\right)$ during fermentation process [48]; [76]. The configuration ratio $(\mathrm{P} / \mathrm{L})$ reflecting the balance of the alveogram, had increased with the yam flour incorporation proportion in current study, and this attest the low extensible dough from these composites. The increase of bread dough tenacity combined with a decrease of its extensibility contributed to the decrease of this configuration ratio (P/L). The elasticity index (I.e) also decreases in composite flours because of the low gluten in. The elasticity index (I.e) is shows appearance of the curve and reflects the elastic behaviour of the bread dough [77]. Alveogaphic parameters depend essentially of gluten fraction in the "wheat flour". In these conditions, alveogaphic datas depreciated when the composite flour's gluten had decreases. Wheat flour gluten forms bread dough gluten network during the dough kneading. This gluten network is responsible of viscoelastic characteristics and the dough baking strength
[78]. Partial substitution (wheat/yam composite flours) lead to a decrease of the baking strength (or work W). Thus, the baking strength values decreased from 270 to $370 \times 10^{-4} \mathrm{~J}$. These values were higher than those reported by Mepba et al. [79] incorporating plantain flour into wheat one. However, values reported by these authors decreased from 292 to $93.10^{-}$ ${ }^{4} \mathrm{~J}$. Balla et al. [70] reported similar values (210 to $340.10^{-4}$ J) with wheat and sorghum composite flours. The results of this study showed the depreciation of composite flours potential. They are that similar with results reported by countless studies conducted on composite flours in bakeries $[36,70,79]$.

\section{Dough rising speed during fermentation}

The evolution of dough rising volume during fermentation was reported in Fig. 2. Dough pieces had an initial volume of $30.00 \pm 02 \mathrm{~cm}^{3}$. Overall, the dough volume decreased with the increase of yam substitution ratio for the same time of fermentation. For anytime, the rising volume of the control sample (WF) was the highest values while the WYF25 (25\% yam) flour sample gave the lowest values of dough volume. Highest volumes of dough were recorded from 120 to 150 min of fermentation. Values of dough volumes in all the fermentation process were ranged as follows $160.56 ; 142.06$; $130.45 ; 120.07 ; 108.06$ and $100.06 \mathrm{~cm}^{3}$, respectively for flours doughs samples of WF, WYF5, WYF10, WYF15, WYF20 and WYF25. Beyond this time above, dough volumes declined for all composite samples. For all composite flours, the increase of dough volume during the first 120 minutes of fermentation was due to the production of carbon dioxide by yeasts that catalysed starchy sugars fermentation.

This gas is stored in gas cells, which are micronuclei spherical spaces and created by the incorporation of air during the kneading process [36]. The gas production capacity depends of the starch and yeast initial quality. Thus, its retention depends on the quality of the glutinous network. It is then reported that higher the damaged starch of the flour, more likely the amylase activity is still to produce fermentable sugars [51, 63]. High damaged starch is likely to induce high fermentable sugars quantity. However, the results showed a decrease in dough volume when wheat flour was gradually substituted by yam flour. Even if the gas production capacity may be higher in high substituted flours, it seems that a large fraction of this gas is not retained because of the weakness of composite flours dough gluten network. 


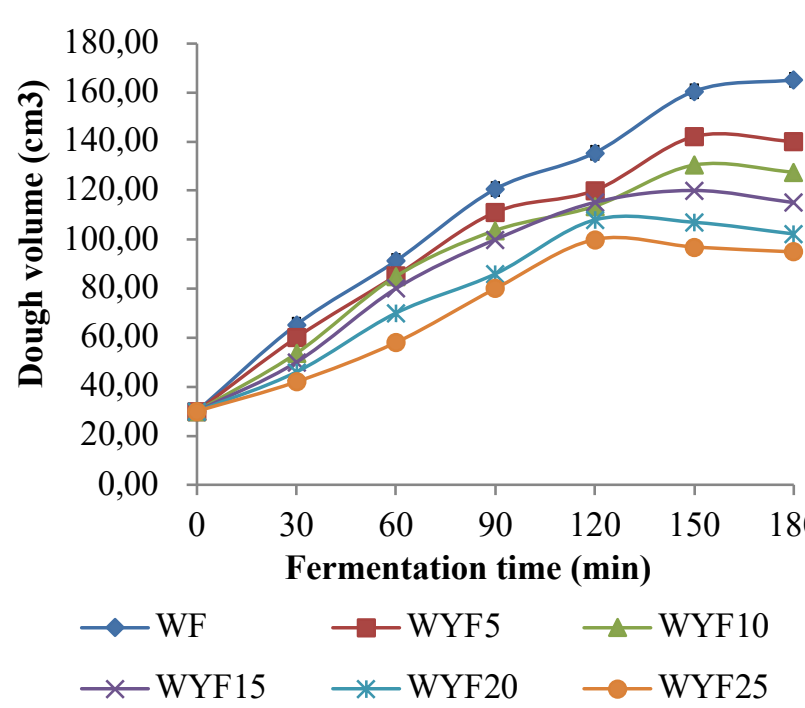

WF $=$ Wheat $/$ Yam: 100:0; WYF5 = Wheat $/$ Yam: 95:5; WYF10= Wheat $/$ Yam 90:10; WYF15= Wheat $/$ Yam: 85:15; WYF20= Wheat $/$ Yam: 80:20; WYFI25= Wheat $/$ Yam: 75:25.

Fig. 2. Evolution of composite flours Dough volume versus fermentation time.

During the kneading and fermentation processes, gluten network reinforces itself later as reported by Buche [46]. The author, measured the rate of gas production and retention since kneading process and he found that the gas production was better during the kneading than that obtained at the others processes of bread making last. The most important part of fermentation takes place in the middle of the dough film and in anaerobiosis, while $95 \%$ of glucose is metabolized via alcoholic fermentation by yeast [80]. According to Buche [46], fermentation continues at the beginning of cooking with the increase of the temperature of the dough to reach $50{ }^{\circ} \mathrm{C}$ and then it is accelerated and stopped by thermo-destruction of the yeast. Fermentation is a key process of bread quality criterion as the presence of micro-bubbles of gas induce the good alveolar structuring of the crumb of the bread [81, 82]. In addition, obtaining cohesive and viscoelastic gluten network also ensures the retention of ethanol and aromas during the fermentation process $[46,78]$.

\section{E. Subjective visual characteristics of Yam and wheat composite breads}

The incorporation of yam flour into wheat flour did not have significant effect on crumbs colour (Fig. 3). This result of breadcrumbs showed that the wheat flour substitution by yam flour decrease the loaves volume. Similarly, the crust thickness and the size of the alveolar cells appeared to decrease with the increase of the yam incorporation level ( $15 \%$ of yam flour). This was in contradiction with previous works conducted by Meité et al. [83], showing that it was possible to obtain composite breads without significant difference $(\mathrm{p} \leq 0.05)$ in crust thickness. According to Roussel et al. [63], the "normal" thickness is about $1 \mathrm{~mm}$. An apparent value greater than $1 \mathrm{~mm}$ is supposed to be in "excess"; conversely, an apparent thickness less than $1 \mathrm{~mm}$ is noted in "deficiency". In this work, the thickness of the crust for high substituted composites loaves $(15 \%, 20 \%$ and $25 \%$ of yam flours) seems insufficient. Reguerre et al. [84] showed that bread crust thickness was strongly and positively correlated to baking time. These authors reported that crust thickness could reach $4 \mathrm{~mm}$ for baking time of 25

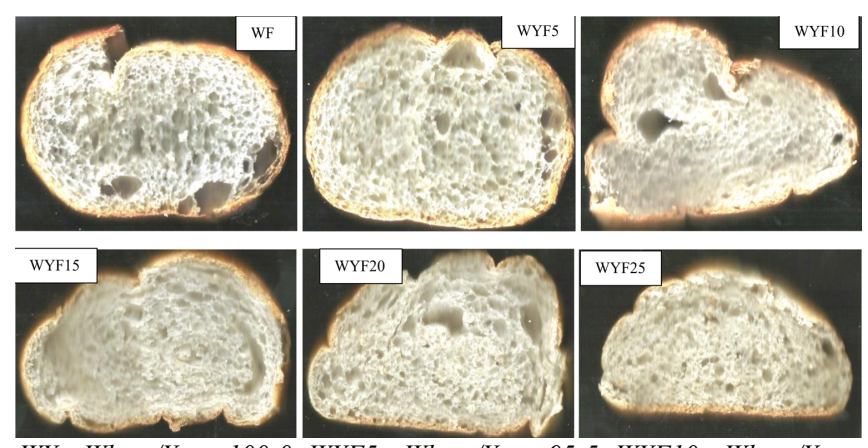

WY $=$ Wheat $/$ Yam: 100:0; WYF5 $=$ Wheat $/$ Yam: 95:5; WYF10 $=$ Wheat $/$ Yam 90:10; WYF15= Wheat/Yam: 85:15; WYF20=Wheat/Yam: 80:20; WYF25= Wheat/Yam: 75:25

Fig.3. Pictures of breads crumb and alveoli (scanned images at $300 \mathrm{dpi}$ ).

to $30 \mathrm{~min}$. But, according to Reguerre et al. [84], the ideal bread crust thickness should range from 2.5 to $3 \mathrm{~mm}$.

In current study, variations of breads thickness should rather be attributed to the variation of the substitution (Wheat/Yam flours) level.

\section{F. Physical characteristics of breads samples}

Physical characteristic showed significant variations in loaves properties (Table 4). Thus, the mass, volume and specific volume of loaves ranged from 201.66 to $231.66 \mathrm{~g}$; from 314.33 to $658.00 \mathrm{~cm}^{3}$ and from 1.37 to $3.26 \mathrm{~cm}^{3} / \mathrm{g}$, respectively. The increase of breads weight may be due to the higher water absorption and hydration capacities of composite doughs. The increase of breads weight with the increase of yam flour incorporation to wheat flour was similar to the results reported by Amandikwa et al. [26], testing the substitution of wheat flour by various yam flours in bread making. Similar results were also reported by Amal [85] with the incorporation of sweet potato flour (Ipomoea batatas) into wheat flour at break mating. The loaves volume and the specific volume have decreased proportionally with the increase of the yam flour in the formulation. This evolution induced the increase of the breads density (or specific weight). The decrease of loaves volume is one of the depreciation of breads quality. This was likely to be responsible of the increase of the alveolar density, with cells size becoming more smallers. From $10 \%$ of yam flour incorporation to wheat flour, the specific volumes of this study (from 2.67 to $3.26 \mathrm{~cm} 3 / \mathrm{g}$ ) were close to those of Ukpabi [86], incorporating yam flour D. esculentata to wheat flour. When wheat flour substitution ratio was higher than $10 \%$, lower values of specific volumes ( 1.37 to $1.91 \mathrm{~cm} 3 / \mathrm{g}$ ) has been observed. These values are coherent with those reported by Amandikwa et al. [26]. However, values in current work are lower than those (from 2.55 to 4.57) obtained with sweet potato by Amal [85]. Decreasing volumes with increasing substitution level are coherent with previous results reported by Greene and Bovell-Benjamin [87] using sweet potato flour at wheat flour substitute. Burton [88] and Meité et al. [83] reported that breads obtained from potato flour and Citrullus lanatus seed flour incorporation respectively into wheat flour produced higher volumes of breads. The decrease of composite breads volume in the current study is associated to lower gluten content of composite flour and the weakness of its network in the final doughs. In these conditions, less gas was retained in alveolar cells during the fermentation [89]. 
TABLE 4: VOLUME AND DENSITY OF COMPOSITE BREADS DEPENDING OF THE LEVEL OF YAM FLOUR SUBSTITUTED TO WHEAT FLOUR

\begin{tabular}{|c|c|c|c|c|c|c|}
\hline \multirow{3}{*}{ Physical properties of breads } & \multicolumn{6}{|c|}{ Incorporation rate of yam flour } \\
\hline & WF & WYF5 & WYF10 & WYF15 & WYF20 & WYF25 \\
\hline & $\mathbf{0} \%$ & $5 \%$ & $10 \%$ & $15 \%$ & $20 \%$ & $25 \%$ \\
\hline Mass (g) & $201.66 \pm 2.33^{\mathrm{a}}$ & $207.66 \pm 1.66^{\mathrm{a}}$ & $218.66 \pm 1.45^{\mathrm{b}}$ & $225.33 \pm 1.00^{\mathrm{c}}$ & $227.66 \pm 0.73^{\text {cd }}$ & $231.66 \pm 2.00^{\mathrm{d}}$ \\
\hline Volume $\left(\mathrm{cm}^{3}\right)$ & $658.00 \pm 4.33^{\mathrm{a}}$ & $624.00 \pm 3.33^{\mathrm{a}}$ & $584.66 \pm 3.00^{\mathrm{b}}$ & $429.33 \pm 0.83^{\mathrm{c}}$ & $319.00 \pm 2.77^{\mathrm{d}}$ & $314.33 \pm 2.33^{\mathrm{d}}$ \\
\hline Density (specific weight) $\left(\mathrm{g} / \mathrm{cm}^{3}\right)$ & $0.31^{\mathrm{a}}$ & $0.33^{\mathrm{a}}$ & $0.37^{\mathrm{ab}}$ & $0.52^{\mathrm{b}}$ & $0.71^{\mathrm{c}}$ & $0.73^{\mathrm{c}}$ \\
\hline Specific volume $\left(\mathrm{cm}^{3} / \mathrm{g}\right)$ & $3.26^{\mathrm{a}}$ & $3.00^{\mathrm{a}}$ & $2.67^{\mathrm{c}}$ & $1.91^{\mathrm{bc}}$ & $1.40^{\mathrm{c}}$ & $1.37^{\mathrm{c}}$ \\
\hline
\end{tabular}

Gluten is essential to ensure the viscoelastic properties of dough [90]. Ndangui [89] reported that starch gelatinization level could be responsible of these facts. Consequently, the volume reduction leaded to decrease commercial quality and should be limited consumers choice. Generally, consumers and bakers, consider the specific volume and the alveolar structure of the breads [91]. In these conditions, correctors or improvers are frequently used in bread making to increase the volume of bread [92] and to ensure acceptable trading value. Without these kinds of corrections, the development of composite breads using more than $10 \%$ of D. praehensilis flour should be in the field of special breads.

\section{G. Sensory characteristics}

Breads were characterized evaluating their crust and crumb colour, appearance, aroma, taste and texture for their overall acceptability. Bread quality has depreciated when the substitution of wheat and yam level was increased (Table 5).

This quality is conform with the quality of composite breads made from wheat and yam flour by Ukpabi [86], Amandikwa et al., [26], sweet potato by Amal [85], Ndangui [89] and sorghum by Balla et al. [70]. In this study, below $10 \%$ of wheat flour substitution by yam flour, all evaluated criteria maintained results higher than average of 4.5 points on a 9-point hedonic scale. Above $10 \%$ of yam flour incorporation to wheat flour, results were lower than this average. Only the crumb colour, the aroma and the taste of breads gave higher results than the witness bread. The lowest values were reported at $25 \%$ of yam flour substitution to wheat flour, with 1.66, 2.03 and 1.33 respectively for Crust colour, the texture (crunchiness) and overall acceptability. Regarding these results, it can be noted that below $10 \%$ of yam flour incorporated to wheat flour, the composite Wheat / yam breads are globally acceptable, and the acceptability threshold should be between 10 and $15 \%$ of yam flour incorporation to wheat flour for the development of ordinary breads.

\section{CONCLUSION}

The incorporating of wild yam $D$. praehensilis flour into wheat flour led to decrease in key parameters such as Gluten content, Zeleny and the Hagberg falling indexes of the dough. Thus, composites flours of high yam flour content had a low gluten content. This low level of gluten leaded to decrease the Hagberg falling index slightly as a function of yam flour quantity. The amylase's activities and the Zeleny index of the composite flour depended to the high damaged starch fraction of yam flour. This damaged starch level was responsible of the high hydration of substituted flours necessary to perform the kneading process. Few rheological tests executed with the Alveograph Chopin, confirmed the increasing of composite dough hardness, making it difficult to knead and to shape. It would not be possible to make decent breads incorporating more than $15 \%$ of yam flour in the wheat flour at breadmaking process. The volume of composite doughs increased during 120 minutes before being steady. The final bread volume decreased, and it became more critical for composite flours containing $15 \%, 20 \%$ and $25 \%$ of yam flour. Physical properties were also lessened from $10 \%$ to $15 \%$ of yam flour substitution to wheat flour but the final bread quality was adequate for $10 \%$ and less. The composite good bread was then obtained for $10 \%$ and less of yam flour incorporation to wheat flour in breaking process. It was that possible to incorporate $10 \%$ of wild yam $D$. praehensilis flour into wheat flour to produce good breads in breadmaking process.

TABLE 5: EVOLUTION OF BREADS CHARACTERISTICS.

\begin{tabular}{|c|c|c|c|c|c|c|}
\hline \multicolumn{7}{|c|}{ Wheat and composite wheat/yam flours } \\
\hline Evaluation criteria & WF & WYF5 & WYF10 & WYF15 & WYF20 & WYF25 \\
\hline Crust color & $8.06 \pm 0.15^{\mathrm{a}}$ & $7.18 \pm 0.22^{\mathrm{ab}}$ & $6.59 \pm 0.18^{\mathrm{b}}$ & $4.03 \pm 1.05^{\mathrm{c}}$ & $3.12 \pm 0.33^{\mathrm{d}}$ & $1.66 \pm 0.66^{\mathrm{e}}$ \\
\hline Crumb Color & $7.34 \pm 0.07^{\mathrm{a}}$ & $7.25 \pm 0.03^{\mathrm{a}}$ & $7.45 \pm 0.09^{\mathrm{a}}$ & $5.66 \pm 0.45^{\mathrm{b}}$ & $5.12 \pm 0.15^{\mathrm{b}}$ & $5.33 \pm 0.20^{\mathrm{b}}$ \\
\hline Crust appearance & $8.27 \pm 0.03^{\mathrm{a}}$ & $7.45 \pm 0.57^{\mathrm{b}}$ & $5.07 \pm 0.77^{\mathrm{c}}$ & $4.05 \pm 0.27^{\mathrm{d}}$ & $3.45 \pm 0.17^{\mathrm{e}}$ & $2.66 \pm 0.22^{\mathrm{f}}$ \\
\hline Aroma & $7.21 \pm 0.11^{\mathrm{a}}$ & $7.37 \pm 0.09^{\mathrm{a}}$ & $6.24 \pm 0.07^{\mathrm{b}}$ & $6.12 \pm 0.06^{\mathrm{b}}$ & $5.66 \pm 0.13^{\mathrm{bc}}$ & $5.33 \pm 0.09^{c}$ \\
\hline Taste & $8.50 \pm 0.02^{\mathrm{a}}$ & $8.38 \pm 0.07^{\mathrm{a}}$ & $6.33 \pm 0,15^{\mathrm{b}}$ & $5.66 \pm 0.09^{\mathrm{c}}$ & $5.33 \pm 0.04^{\mathrm{cd}}$ & $5.24 \pm 0.03^{\mathrm{d}}$ \\
\hline Texture (crunchiness) & $9.12 \pm 0.00^{\mathrm{a}}$ & $6.77 \pm 0.02^{\mathrm{b}}$ & $5.66 \pm 0.04^{\mathrm{c}}$ & $4.33 \pm 0.06^{\mathrm{d}}$ & $2.66 \pm 0.55^{\mathrm{e}}$ & $2.03 \pm 0.07^{\mathrm{e}}$ \\
\hline Global acceptance & $8.70 \pm 0.07^{\mathrm{a}}$ & $7.51 \pm 0.22^{\mathrm{b}}$ & $5.20 \pm 0.15^{\mathrm{c}}$ & $4.66 \pm 0.08^{\mathrm{d}}$ & $3.55 \pm 0.33^{\mathrm{e}}$ & $1.33 \pm 0.03^{\mathrm{f}}$ \\
\hline
\end{tabular}

WY=Wheat $/$ Yam: $100: 0 ;$ WYF5=Wheat/Yam: 95:5; WYF10=Wheat/Yam: 90:10; WYF15=Wheat/Yam: 85:15; WYF20=Wheat/Yam: 80:20; WYF25= Wheat/Yam: 75:25. Each value corresponds to an average of three trials. Values are means \pm standard deviation. Means that do not share a similar letter in a row are significantly different $(p \leq 0.05)$, according to Duncan's test. 


\section{ACKNOWLEDGMENT}

We are grateful to "Laboratoire de Biochimie et Technologie des Aliments de l'Université Nangui Abrogoua, Abidjan, Côte d'Ivoire" for the support of this work. We are grateful to Professor Amani George, Director of the "Laboratoire de Biochimie Alimentaire et de Technologie des Produits Tropicaux de l'Université Nangui Abrogoua", for contribution of the specimen (Dioscorea praehensilis) identification used in the present study.

\section{REFERENCES}

[1] A. Chevalier, Contribution à l'étude de quelques espèces africaines du genre Dioscorea. Bull. Mus., 2e s., t. 8 (1936) 520-551.

[2] FAOSTATS, FAO database (2014). Données rapportées Septembre/Octobre 2017 : http://www.fao.org/faostat/fr/\#data/

[3] O. Girardin, C. Nindjin, Amélioration de la conservation de l'igname en milieu villageois. 1ère partie : Etude de l'amélioration du stockage traditionnel. In Sempervira, Ed. CSRS. Côte d'Ivoire n 5 (1996) 53p.

[4] P. Vernier, J. Hounhouigan, N. Bricas, La transformation des ignames en cossettes et les préparations culinaires dérivées. Eschforn : CIRAD/CERNA/PhAction/GTZ, (2000) 28p.

[5] S. J. Ouedraogo, W.T. Kaboré, Étude sur les pertes post récolte en Afrique de 1'Ouest : cas de quelques pays côtiers et du Sahel. Rapport définitif, (2014) 44p.

[6] N. Verter, V.Bečvářová, An analysis of yam production in Nigeria. Acta Univ. Agric. Silvic. Mendel. Brun., 63(76) (2015) 659-665.

[7] D.A. Sahoré, N.G. Amani, Technical Sheet of Some Wild Yam (Dioscorea) Starch. Int. j. food nutr. Sci. 2(1) (2013) 33-37.

[8] A. Dansi, H.D. Mignouna, J. Zoundjihekpon, A. Sangare, R. Asiedu, F.M. Quin, Morphological diversity, cultivar groups and possible descent in the cultivated yams (Dioscorea cayenensis Dioscorea rotundata complex) of Benin Republic.Genetic Resources Crop Evol., 46, (1999) 371-388.

[9] E.S. Ayensu, D.G. Coursey, Guinea yams: the botany, ethnobotany, use and possible future of yams in west Africa. Econ. Bot., 24 (1972) 301-318.

[10] A. Hladik, S. Bahuchet, C. Ducatillon, C.M. Hladik, Les plantes à tubercules de la forêt dense d'Afrique Centrale. Rev. Ecol. 39 (1984) 248290

[11] P. Hamon, Structure, origine génétique des Ignames en Afrique de I'Ouest. These de Doctorat es-Sciences. Université Paris XI, Centre d'Orsay (1987) $223 \mathrm{pp}$.

[12] R. Dumont, Rapport de mission au Gabon. CIRAD-IIRSDAIITA. Unité de Coordination des Recherches sur l'Igname. Du 10 au 13 mai (1993) 8 p.

[13] R. Dumont, Rapport de mission en Centrafrique. CIRADIIRSDA-IITA. Unité de Coordination des Recherches sur l'Igname. Du 14 au 19 mai (1993) $5 \mathrm{p}$.

[14] N.G. Amani, S. Coulibaly, C. Nindjin, F. Tetchi, Répertoire de technologie de conservation et de transformation de l'igname et de la banane plantain. FIRCA (2010) 161p.

[15] D.G. Coursey, C.E.M. Ferber, The processing of yams, In: Small-scale Processing and Storage of Tropical Root Crops. (Plucknett Eds.), Westview Press, Colorado, USA (1979) pp 15-25.

[16] N. Bricas, P. Vernier, E. Ategbo, J.D. Hounhoiugan, E. Mitchkpe, K.E. N'Kpenu, G. Orkwor, The development of pounded machine in West Africa. J. Res. Dev., 44 (1997) 100-114.

[17] R. Dumont, Utilisation des ignames (Dioscorea spp.) pour la production de cossettes ou de farine destinée au commerce. Situation actuelle et perspectives. Rapport, CIRAD/IITA, Cotonou, République du Bénin, (1995) $7 \mathrm{p}$.
[18] R.R. Rosario, P.B. Malit, Improved ubi (Dioscorea alata L.) flour preparation and its utilization for instant halaya. Philippine Agr. 67 (1984) $177-182$.

[19] P. Osswald, Économie des racines et tubercules. Analyse dans les pays d'Afrique de l'Ouest et du Centre. Solagral, Paris, France (1995).

[20] FAO, Composite flour program, documentation package, FAO, Rome, Italy (1971).

[21] H. Ducroquet, P. Tillie, K. Louhichi, S. Gomez-Y-Paloma, L'agriculture de la Côte d'Ivoire à la loupe : Etat des lieux des filières de production végétales et animales et revue des politiques agricoles. Rapport JRC, Joint Research Center, European Commission. (2017) 244p.

[22] E. Ohimain, A. Decade (2002 - 2012) of Presidential Intervention on Cassava in Nigeria; the Successes and Challenges. Asian J. Agric. Extens. Econ. Sociol. AJAEES, 6(4) (2015) 185-193.

[23] PPAAO/WAAPP, Technologie Du Pain Composé : Production de pains de qualité à base de farines composées, formulées à partir de $15 \%$ de farine locale (maïs ou manioc) et $85 \%$ de farine de Blé. Programme de Productivité Agricole en Afrique de l'Ouest pour le Bénin (PPAAO/WAAPP) (2016). http://www.waapp-ppaao.org/cotedivoire/technologie-du-pain-compose/

[24] G.M. Sammy, Studies in composite flour: I -the use of sweet potato in bread and pastry making. Trop Agric., 47 (1970) 125-155.

[25] A.S. Trejo-González, A.G. Loyo-González, M.R. MunguíaMazariegos, Evaluation of bread made from composite wheat-sweet potato flours. Int Food Res J, 21(4) (2014) 1683-1688.

[26] C. Amandikwa, M.O. Iwe, A. Uzomah, A.I. Olawuni, Physicochemical properties of wheat-yam flour composite bread. Niger. Food J., 33(1) (2015) 12-17.

[27] M. Eduardo, Enhancing Composite Cassava Bread Quality: Effect of cassava pre-treatment and baking improvers. Ph.D Department Of Biology And Biological Engineering, Food And Nutrition Science, Chalmers University Of Technology Göteborg, Sweden (2015) 80p.

[28] A. Bell, J.C. Favier, Influence des transformations technologiques traditionnelles sur la valeur nutritive de l'igname au Cameroun. Biology, 12, (1982) 135-150.

[29] AACC, Method 38-12; method 56-8; method 76-33, Approved Methods. Am. Assoc. Cereal Chem. St Paul, Minnesota, USA (2000).

[30] C.A. Koko, A. Konan, F. Tétchi, E. Assidjo, G. Amani, Quality of fermented cassava flour processed into placali. Int. J. Biol. Chem. Sci. 6(1) (2012) 415-420.

[31] R. Cubadda, M. Carcea, L.A. Pasqui, Suitability of the gluten index test for assessing gluten strength in durum wheat and semolina. Cereal Foods World 37 (1992) 866-869.

[32] R.G. Kulkarni, J.G. Ponte, K. Kulp, Significance of gluten content as an index of flour quality. Cereal Chem., 64 (1987) 1-3.

[33] D.N. Abang Zaidel, N.L. Chin, Y.A., Yusof, A review on rheological properties and measurements of dough and gluten. J. Appl. Sci. 10 (2010) 2478-2490

[34] M. Başlar, M.F. Ertugay, Determination of protein and gluten qualityrelated parameters of wheat flour using near-infrared reflectance spectroscopy (NIRS). Turk J Agric For 35 (2011) 139-144.

[35] T.A-H. Tawakalit, Characteristics of Yam Composite Flour: Properties And Function of Bread And Tortilla Making. PhD., North Dakota State University of Agriculture and Applied Science (2017) 187p.

[36] H.A. Bakare, F.O. Oluwatooyin, J.O. Olusanya, Rheological, baking, and sensory properties of composite bread dough with breadfruit (Artocarpus communis Forst) and wheat flours. Food Sci. Nutr. 4(4) (2016) 573-587.

[37] B. Godon, Les constituants des céréales : nature, propriétés et teneurs. In : Biotransformation des produits céréaliers. ED Tec. Et Doc. Lavoisier, Paris (1991) 22p. 
[38] K. Ghiasi, R.C. Hoseney, E. Varriano-Marston, Effects of flour components and dough ingredients on starch gelanitization. Cereal Chem. 60 (1) (1993) 58-61.

[39] S.Ragaee, E.M. Abdel-Aal, Pasting properties of starch and protein in selected cereals and quality of their food products. Food Chem., 95 (2006) 9-18.

[40] A.H. Bloksma, Dough structure, dough rheology, and baking quality. Cereal Food World 35 (1990) 237-244.

[41] E. Gallagher, T.R. Gormley, E.K. Arendt, Crust and crumb characteristics of gluten free breads. J. Food Eng, 56 (2003) 153-161.

[42] B.K. Baik, I.H. Han, Cooking, roasting, and fermentation of chickpeas, lentils, peas, and soybeans for fortification of leavened bread. Cereal Chem. 89 (2012) 269-275.

[43] I. Mohammed, A.R. Ahmed, B. Senge, Dough rheology and bread quality of wheat-chickpea flour blends. Industr. Crops Prod. 36 (1) (2012) 196-202.

[44] M. Noorfarahzilah, J.Lee, M. Sharifudin, A. Mohd Fadzelly, M. Hasmadi, Applications of composite flour in development of food products. Int. Food Res. J., 21(6) (2014) 2061-2074.

[45] N. Tharise, E. Julianti, M. Nurminah, Evaluation of physico-chemical and functional properties of composite flour from cassava, rice, potato, soybean and xanthan gum as alternative of wheat flour. Int Food Res J, 21(4) (2014) 1641-1649.

[46] F. Buche, Influence de la formulation de pâtes de farine de blé sur leur consommation d'oxygène et leur production de dioxyde de carbone au cours du pétrissage et de la fermentation : Conséquences biochimiques et rhéologiques. Alimentation et Nutrition. THÈSE, Sciences des Aliments, Institut des Sciences et Industries du Vivant et de l'Environnement, (AgroParisTech), (2011) 408p.

[47] G. Kleijer. Sélection des variétés de blé pour la qualité boulangère. Station Fédérale de Recherches en Production Végétale de Changins. Rev Suisse Agric., 34 (2002) 253-259.

[48] B. Godon, W. Loisel. Guide pratique d'analyses dans les industries des céréales. Edit. TEC et DOC, Lavoisier, (1997) 317-589.

[49] M. Sambe, L.S. Tounkara, M.J.F.S. Lopy, Y. N'diaye, Etude des comportements rheologiques des melanges de farine ble/sorgho sans tanins issue de trois nouvelles varietes cultivees au senegal et mise au point de pains à base de farines composees (ble/sorgho). Agron. Afr. 29 (1) (2017) 69 - 74.

[50] N.G.J.M. Medoua, Potentiels nutritionnel et technologique des tubercules durcis de l'igname Dioscorea dumetorum (Kunth) pax : Étude du durcissement post-récolte et des conditions De transformation des tubercules durcis en farine. Thèse de Doctorat. (2005) 254p.

[51] Amrouche, Du blé au pain (2012)

http://genie-alimentaire.com/spip.php?article92

[52] S. Barak, D. Mudgil, B.S. Khatkar, . Effect of flour particle size and damaged starch on the quality of cookies. J Food Sci Technol 51(7) (2014) 1342-1348.

[53] A. Becker, S.E. Hill, J.R. Mitchell, Milling - a further parameter affecting the Rapid Visco Analyser (RVA) profle. Cereal Chem, 78(2) (2001) 166-172.

[54] R.F. Tester, W.R. Morrison, Properties of damaged starch granules. V. Composition and swelling of fractions of wheat starch in water at various temperatures. J. Cereal Sci., 20(2) (1994)175-181.

[55] R.C. Hoseney, Principles of cereal science and technology ( $2^{\text {nd }}$ ed.). St. Paul, MN: Am. Assoc. Cereal Chem. 81 (1994) 229-273.

[56] D. Živančev, A. Torbica, J. Mastilović, D. Knežević, N. Đukić, Relation among Different Parameters of Damaged Starch Content, Falling Number and Mechanical Damage Level. Ratar. Povrt. 49:3 (2012) 282-287.

[57] C. David, J. Abecassis, M. Carcea, F. Celette, G.Corre-Hellou, J. Friedel, J. Hiltbrunner, P. Mader, M. Messmer, V. Narducci, J. Peigné, I.K.Thomsen, Améliorer la qualité technologique, nutritionnelle et sanitaire du blé biologique: Principaux leviers agronomiques et technologiques. Innov. Agron. 32 (2013) 1-13.

[58] Z. Huang, J. Lu, X. Li, Z. Tong, Effect of mechanical activation on physico-chemical properties and structure of cassava starch. Carbohydr. Polym., 68(1) (2007) 128-135.

[59] W.E. Barbeau, C.A. Griffey, Z. Yan, Evidence that minor sprout damage can lead to significant reductions in gluten strength of winter wheats. Cereal Chem. 83 (2006)306-310.

[60] W.E. Thomason, K.R. Hughes, C.A. Griffey, D.J. Parrish, W.E. Barbeau, Understanding Pre-harvest Sprouting of Wheat. Virginia Polytechnic Institute and State University, Virginia Cooperative Extension, Virginia Tech, publication 424-060 (2009).

[61] P. Wade, Biscuits, Cookies and Crackers: The Principles of Craft.1 (1988) 1-4.

[62] N.L. Kent, A.D. Evers, Chemical components. Technology of Cereal, 4th edition, Pergamon Press (1994) 55-77.

[63] P. Roussel, H. Chiron, G. Della Valle, N. Ndiaye, Recueil de connaissances sur les descripteurs de qualité des pâtes et des pains ou variables d'état pour la panification française: Glossaire terminologique appliqué aux pains français. IRNA, Polytech, Paris-UPMC (2010) 66p.

[64] G.S. Ranhotra, J.A. Gelroth, G.R. Eisenbraun, Correlation between chopin and AACC method of determining damaged starch. Cereal Chem 70 (1993) 235-236.

[65] R. Calvel, Le pain et la panification. In col. «Que sais-je ? », n¹140, ISSN 0768-0066; Cop., Presses universitaires de France, Paris, 1964, 1 vol. III (1964) 127p.

[66] F. Langraf, Produits et procédés de panification. Edit. Technique de l'ingénieur, traité Agroalimentaire, Rouen (2008) 12p.

[67] P. Roussel, Qualités technologiques. Dossier ENSMIC (2005)

[68] K.H. Tipples, Relation of starch damage to the baking performance of flour. Baker's Digest, 43(6) (1969) 28-32.

[69] G.N. Barrera, G.T. Perez, P.D. Ribotta, A.F. Leon, Influence of damaged starch on cookie and bread-making quality. Eur Food Res. Technol., 22(5) (2007) 1-7.

[70] A. Balla, C. Blecker, M. Oumarou, M. Paquot, C. Deroanne, Mise au point de pains composites à base de mélanges de farines de sorgho-blé et analyse texturale. Biotechnol. Agron. Soc. Environ. 3 (2) (1999) 69-77.

[71] R. Guinet, B. Godon, La panification française. Edit. Lavoisier-Apria, Tec et Doc, Paris (1994) 534 p.

[72] O. Laabidi, Etude Rhéologlque et Microbiologique d'une Farine Traitée par Irradiation. Memoire, Ingenieur, Ecole Superieure Des Industries Alimentaire, Tunis (2007) 96p.

[73] G. Branlard, B. Meleard, F-X. Oury, L. Rhazi, N. Boinot, Club5, CETAC. Compréhension du rapport "Ténacité/ Extensibilité" et du volume du pain ; $2008 \mathrm{~K}$ (2008) 18-26.

[74] D.D. Kasarda, J.E. Bernardin, C.C. Nimmo, Wheat proteins. Adv Cereal Sci Technol., ed. by Y. Pomeranz, AACC, St. Paul, MN, 1 (1976) 158-236.

[75] F.R. Huebner, J.A Bietz, K.S. Wall, Protein Crosslinking, Biochemical, and Molecular Aspects. Friedman, M., Ed.; Plenum Press: New York (1977) $67 \mathrm{p}$.

[76] N. Sakr, E. Hajj Moussa, Comparaison de la qualité des blés libanais à celle des variétés importées de l'étranger et destinées à la préparation du pain libanais. Liban Sci J, 8 (2007) 87-103.

[77] P. Kitissou, Un nouveau parametre alvéographique: L'indice d'élasticité (Ie). Ind Céréal, (1995) 9-13.

[78] P. Feillet, Le grain de blé, composition et utilisation. Edit Institut national de la recherche agronomique INRA, paris (2000) 308p. 
[79] H.D. Mepba, L. Eboh, S.U. Nwaojigwa, Chemical composition, functional and baking properties of wheat-plantain composite flours. Afr. J. Food Agric. Nutr. Dev., 7(1) (2007) 1-22.

[80] R. Drapron, J. Potus, F. Laplume, P. Potus, Notre pain quotidien. Edition AGP, Paris. (1999)

[81] K.L. Meehta, M.G. Scanlon, H.D. Sapirstein, J.H. Page, Ultrasonic investigation of the effect of vegetable shortening and mixing time on the mechanical properties of bread dough. J. Food Sci., 74 (2009) 455-461.

[82] B.F. Pareyt G. Talhaoui, K. Kerckhofs, H. Brijs, M. Goesaert, J. Wevers, A. Delcour. The role of sugar and fat in sugar-snap cookies: Structural and textural properties. J. Food Engineer. 90(3) (2009) 400-408.

[83] A.Meité, K.G. Kouame, N.G. Amani, Kati-Coulibaly, A. Offoumou, Caractéristiques physico-chimiques et sensorielles des pains fortifiés avec les farines de graines de citrullus lanatus. J. Sci. Pharm. Biol., 9(1) (2008) 32 43.

[84] A-L. Reguerre, M.F. Devaux, H. Chiron, M. Raitiere, Suivi de l'apparition de la croûte du pain par imagerie. Cah. Tech. INRA (74) (2011) $14-29$.

[85] A.M. Amal, Quality evaluation of wheat-sweet potato composite flours and their utilization in bread making. Int. J. Adv. Res. Biol. Sci. 2(11) (2015) 294-303

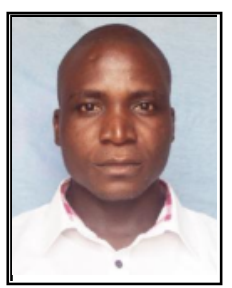

Soro Songuimondenin:

Researcher in Biochemistry and Food Science. BSc (UNA, Côte d'Ivoire), MSc (UNA, Côte d'Ivoire), $\mathrm{PhD}$ (in progress UNA, Côte d'Ivoire).

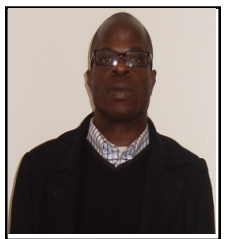

\section{Kouassi-Koffi Jean Didier*}

Lecturer in Biochemistry and Food Science. BSc (UNA, Côte d'Ivoire), MSc (UNA, Côte d'Ivoire), $\mathrm{PhD}$ (AgroParisTech, France in 2009),

(Corresponding author)

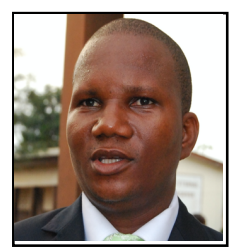

Konan Kouassi Hubert,

Lecturer in Biochemistry and Food Science. BSc (UNA, Côte d'Ivoire), MSc (UNA, Côte d'Ivoire), PhD (UNA, Côte d'Ivoire)

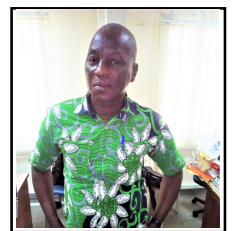

Kouadio Eugène Jean Parfait,

Professor in Biochemistry and Food Science. BSc (UNA, Côte d'Ivoire), MSc (UNA, Côte d'Ivoire), $\mathrm{PhD}$ (UNA, Côte d'Ivoire).
[86] U.J. Ukpabi Farmstead bread making potential of lesser yam (Dioscorea esculenta) flour in Nigeria. Aust. J. Crop Sci. 4 (2010) 68 -73.

[87] J.L. Greene, A.C. Bovell-Benjamin, Macroscopic and sensory evaluation of bread supplemented with sweet-potato flour. J. Food Sci., 69 (2004) 167-173.

[88] W.G. Burton, The potato 3rd ed. London, U.K.: Longman. (1989) 338p.

[89] C.B. Ndangui, Production et caractérisation de farine de patate douce (Ipomoeabatatas.Lam) : optimisation de la technologie de panification. Thèse de Doctorat en Procédés et Biotechnologiques Alimentaires, Université De Lorraine, France, Université Marien Ngouabi, Congo. (2015) $151 \mathrm{p}$.

[90] J.C. Okaka, Bread making ingredients and technology In: Handling, Storage and Processing of plant foods. OCJ Publishers, Enugu (2005) 45-78.

[91] L. Benatallah, Couscous et pain sans gluten pour malades cœliaques : aptitude technologique de formules à base de riz et de légumes secs. Thèse de Doctorat. Institut de la Nutrition, de l'Alimentation et des Technologies Agro-alimentaires I.N.A.T.A.A. (2009) 169p.

[92] C. Saidou, Propriétés physico-chimiques et fonctionnelles des gommes hydrocolloîdes des écorces de Triumfetta cordifolia et Bridelia thermifolia. Thèse de Doctorat. Université de Grenoble, (2012) 235p. 